\title{
Nudności i wymioty towarzyszące wysokoemetogennej chemioterapii — analiza klinicznej praktyki
}

\author{
Adam Płużański
}

Wstęp. Nudności i wymioty (NiW) są częstymi objawami niepożądanymi leczenia przeciwnowotworowego. Wprowadzenie do klinicznej praktyki leków z grupy antagonistów receptora dla 5-hydroksytryptaminy (a5-HT3) i antagonistów receptora dla neurokininy 1 (aNK1) istotnie poprawiło kontrolę NiW wczesnych i późnych. Pomimo istnienia wytycznych dotyczących zasad doboru leków przeciwwymiotnych w zależności od rodzaju chemioterapii, według danych pochodzących z piśmiennictwa w codziennej praktyce klinicznej odsetek kontroli NiW jest niewystarczający. Celem pracy jest przedstawienie i omówienie wyników badania obserwacyjnego dotyczącego zastosowania profilaktyki przeciwwymiotnej u chorych poddanych chemioterapii z udziałem cisplatyny w dawce większej niż $70 \mathrm{mg} / \mathrm{m}^{2} \mathrm{w} \mathrm{ra-}$ mach rutynowej klinicznej praktyki w ośrodkach onkologicznych w Polsce.

Materiał i metody. W okresie od czerwca do lipca 2013 roku przeprowadzono badanie ankietowe w grupie 50 onkologów pracujących w ośrodkach onkologicznych w Polsce. Badanie składało się z kwestionariusza dotyczącego opinii lekarzy na temat stosowania leczenia przeciwwymiotnego oraz wypełnianych przez lekarzy kart obserwacji chorych, w których opisywano postępowanie przeciwwymiotne w rutynowej praktyce klinicznej. Zebrano dane medyczne 200 chorych, u których zastosowano chemioterapię zawierającą cisplatynę w dawce przekraczającej $70 \mathrm{mg} / \mathrm{m}^{2} \mathrm{po}-$ wierzchni ciała. Analizowano częstość ordynowania poszczególnych leków, czas trwania leczenia przeciwwymiotnego oraz stopień kontroli NiW.

Wyniki. U 41\% ankietowanych lekarzy brak skuteczności profilaktyki jest głównym problemem związanym z prowadzeniem leczenia przeciwwymiotnego. W pierwszej dobie wysokoemetogennej chemioterapii schemat trójlekowy zawierający aprepitant (lek z grupy aNK1), antagonistę receptora 5-HT3 (a5-HT3) i deksametazon (dex) zastosowano u 44\% chorych, a a5-HT3 w skojarzeniu z dex u 40\%. W drugiej i trzeciej dobie aNK1 w skojarzeniu z dex zastosowano u $23 \%$ i $26 \%$ chorych, zaś dex w czwartej dobie otrzymało $27 \%$ chorych oraz 7\% - w skojarzeniu z a5-HT3. Średni czas podawania aNK1 wyniósł 3 dni, a5-HT3 - 5,8 dnia, a kortykosteroidów - 5,1 dnia. U 80\% chorych po zakończeniu hospitalizacji wydano receptę na preparaty przeciwwymiotne, z których ponad 60\% stanowił a5-HT3, a dex - 28\%. Całkowitą kontrolę NiW wczesnych uzyskano u $46 \%$, a późnych u $61 \%$ chorych. U $14 \%$ chorych zanotowano nudności przepowiadające, którym u $1 \%$ chorych towarzyszyły wymioty. Według skali wzrokowo-analogowej (VAS - visual-analogue scale) najlepsza kontrola nudności wczesnych i opóźnionych dotyczyła schematu trójlekowego (VAS - 1,48 pkt) w porównaniu ze schematem dwulekowym (VAS - 1,83 pkt) i monoterapią (VAS - 2,3 pkt).

Wnioski. W porównaniu z poprzednim opracowaniem obserwuje się poprawę w zakresie kontroli NiW u chorych otrzymujących wysokoemetogenną chemioterapię. Prawdopodobnie jest to związane z częstszym stosowaniem nowych leków przeciwwymiotnych, jednak stopień zgodności postępowania z obowiązującymi wytycznymi pozostaje niezadowalający. W celu poprawy kontroli NiW istnieje potrzeba stałych szkoleń i monitorowania właściwego leczenia wspomagającego.

Klinika Nowotworów Płuca i Klatki Piersiowej

Centrum Onkologii — Instytut im. Marii Skłodowskiej-Curie

w Warszawie 


\section{Chemotherapy-induced nausea nad vomiting — analysis of clinical practice}

Introduction. Chemotherapy-induced nausea and vomiting (CINV) are common adverse events of antineoplastic treatment. Introduction of the 5-hydroxytryptamine receptor antagonists (a5-HT3) and neurokinin-1 receptor antagonist (aNK1) to clinical practice reduced the acute and delayed CINV. Based on available clinical data, the rate of CINV control in routine practice is unsatisfactory despite the consensus guidelines and recommendations for antiemetic prophylaxis. The purpose of this observational study was to evaluate the pattern of routine antiemetic prophylaxis at oncological units in Poland, where the treatment of patients with highly emetogenic (HEC) cisplatin based chemotherapy at the dose above $70 \mathrm{mg} / \mathrm{sqm}$ is performed.

Material and methods. From June to July 2013,50 oncologist were requested to complete a questionnaire about their opinion on the antiemetic treatment. Additionally, 200 observation cards of patients receiving cisplatin-based chemotherapy at dose more than $70 \mathrm{mg} / \mathrm{sqm}$ and routine antiemetic prophylaxis were collected. The frequency of particular drug administration, duration of antiemetic treatment and CINV control rate were analysed.

Results. The main issue of CINV treatment, as reported in $41 \%$ of questionnaire, was the lack of efficacy of antiemetic prophylaxis. On day 1, HEC three-drug regimen: aprepitant - aNK1, a5-HT3 and dexamethasone (dex) was administered to $44 \%$ patients and combination of a5-HT3 with dex to $40 \%$ of patients. On day 2 and 3, aNK1 with dex was administrated to $23 \%$ and $26 \%$ patients, respectively. $27 \%$ of patients received dex in day 4 and $7 \%$ - in combination with a5-HT3. An average time of aNK1 treatment was 3 days, of a5-HT3 - 5.8 days and of corticosteroids -5.1 days. $80 \%$ of patients were advised to take antiemetic drug at home $(60 \%-\mathrm{a} 5-\mathrm{HT} 3$ and $28 \%-$ dex). Complete control of CINV was observed in $46 \%$ of patients during acute phase and in $61 \%$ patients in delayed phase; $14 \%$ of patients developed anticipatory nausea that caused vomiting in $1 \%$. Analysis of visual analogue scale (VAS) revealed that 3-drug regimen lead to the best control of acute and delayed CINV (VAS score 1.48) compared to 2-drug regimen (VAS score 1.83) and monotherapy (VAS score 2.3).

Conclusions. The CINV control rate is increasing when compared to the previous analysis of the population treated with HEC. This observation correlates with the more frequent use of new antiemetic drugs. However, the rate of adherence to antiemetic guidelines remains unsatisfactory. Continued training and monitoring of the supportive treatment quality is required to improve CINV control.

NOWOTWORY Journal of Oncology 2015; 65, 2: 122-127

Słowa kluczowe: chemioterapia, nudności, wymioty, leczenie przeciwwymiotne

Key words: chemotherapy, nausea, vomiting, antiemetic therapy

\section{Wstęp}

Nudności i wymioty (NiW) związane z chemioterapią należą do najczęstszych powikłań leczenia przeciwnowotworowego. Postrzegane są przez chorych jako główne działanie niepożądane związane z planowaną chemioterapią i negatywnie wpływają na jakość życia. Szacuje się, że w różnym stopniu nasilenia NiW występują nawet u 70 \% poddawanych chemioterapii [1]. Utrzymujące się NiW mogą powodować zaburzenia wodno-elektrolitowe, przyczyniać się do opóźnień i redukcji należnych dawek leków, a w konsekwencji zmniejszać skuteczność leczenia przeciwnowotworowego. Częstość występowania i stopień nasilenia zależy od rodzaju stosowanej chemioterapii, dawki i drogi podania leku, schematu leczenia oraz czynników zależnych od chorego (wiek, płeć, nadużywanie alkoholu, predyspozycje psychiczne). W zależności od ryzyka wystąpienia NiW po chemioterapii u chorych nieotrzymujących profilaktycznego leczenia przeciwwymiotnego leki dzielimy na grupę wysokiego (NiW występujące u ponad 90\% chorych), średniego (30-90\%), niskiego (10-30\%) i minimalnego (poniżej 10\% chorych) ryzyka (tab. I) [2, 3]. Szeroko stosowana w praktyce klinicznej cisplatyna w dawce większej niż $70 \mathrm{mg} / \mathrm{m}^{2}$ należy do grupy leków o wysokim potencjale emetogennym. NiW towarzyszące chemioterapii występujące do 24 godzin od podania cytostatyku - wymioty fazy ostrej (wczesne) — są zależne od uwalniania serotoniny i dopaminy. Istotną rolę w kontroli NiW wczesnych pełnią antagoniści wiązania serotoniny (5-hydroksytryptaminy) z jej receptorem typu 3. (5-HT3 - 5-hydroxytryptamine receptor type-3). Problem do niedawna stanowiły wymioty typu opóźnionego, najczęściej rozpoczynające się w 2. i kolejnych dobach po chemioterapii. Mechanizm ich powstawania jest niezależny od dróg serotoninergicznych, wobec czego aktywność leków z grupy antagonistów 5-HT3 jest niewielka. Mediatorami NiW typu późnego są inne kininy, jak substancja-P czy noradrenalina. Wprowadzenie antagonistów receptora dla neurokininy-1 (NK-1 — neurokinin-1), którego mediatorem jest substancja P, zmniejszyło częstość wymiotów opóźnionych i poprawiło tolerancję leczenia przez chorych. Według aktualnie obowiązujących wytycznych odpowiednie zastosowa- 
Tabela I. Potencjał emetogenny leków przeciwnowotworowych [2]

\begin{tabular}{|c|c|c|}
\hline Stopień ryzyka & Częstość NiW & Lek przeciwnowotworowy \\
\hline Wysoki & $\geq 90 \%$ & $\begin{array}{l}\text { Cisplatyna }>50 \mathrm{mg} / \mathrm{m}^{2}, \text { cyklofosfamid }>1500 \mathrm{mg} / \mathrm{m}^{2}, \text { doksorubicyna } \\
>60 \mathrm{mg} / \mathrm{m}^{2} \text {, epirubicyna }>90 \mathrm{mg} / \mathrm{m}^{2} \text {, ifosfamid }>10 \mathrm{~g} / \mathrm{m}^{2} \text {, dakarbazyna, } \\
\text { karmustyna }>250 \mathrm{mg} / \mathrm{m}^{2} \text {, chlormetyna, streptozocyna, prokarbazyna, } \\
\text { wszystkie schematy złożone z doksorubicyny lub epirubicyny } \\
\text { i cyklofosfamidu }\end{array}$ \\
\hline Średni & $30-90 \%$ & 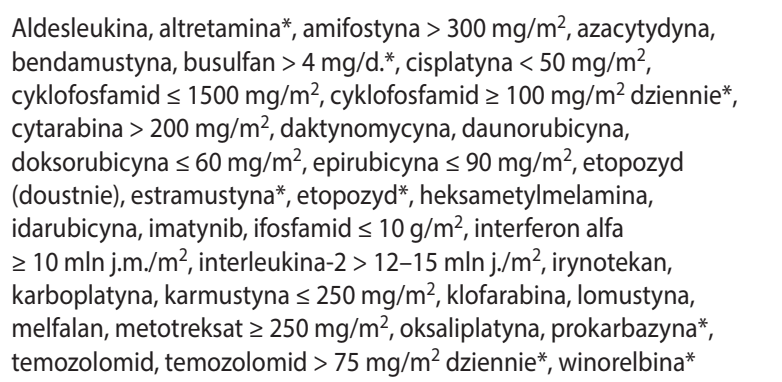 \\
\hline Niski & $10-30 \%$ & 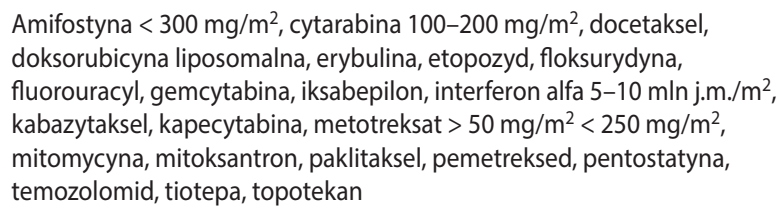 \\
\hline Minimalny & $<10 \%$ & $\begin{array}{l}\text { Alemtuzumab, asparginaza, bewacyzumab, bleomycyna, bortezomib, } \\
\text { busulfan }<4 \text { mg/dziennie*, cetuksymab, chlorambucil (doustnie), } \\
\text { dasatynib, deksrazoksan, erlotynib, ewerolimus, fludarabina, gefitynib, } \\
\text { hydroksymocznik (doustnie), interferon alfa }<5 \mathrm{mln} \text { j.m./m², kladrybina, } \\
\text { melfalan (doustnie), lapatynib, lenalidomid, merkaptopuryna, } \\
\text { metotreksat }<50 \mathrm{mg} / \mathrm{m}^{2} \text {, nelarabina, nilotynib, ofatumumab, } \\
\text { panitumumab, pazopanib, pentostatyna, rytuksymab, sorafenib, } \\
\text { sunitynib, talidomid, temozolomid } \leq 90 \mathrm{mg} / \mathrm{m}^{2} \text { dziennie*, temsyrolimus, } \\
\text { tioguanina (doustnie), trastuzumab, wandetanib, winblastyna, } \\
\text { windezyna, winkrystyna, winorelbina, worinostat }\end{array}$ \\
\hline
\end{tabular}

*wymienione leki stosowane doustnie należą do kategorii ryzyka średniego lub wysokiego

NiW - nudności i wymioty

nie obu grup leków w skojarzeniu z glikokortykosteroidami umożliwia kontrolę NiW zarówno wczesnych, jak i późnych u ponad $70 \%$ chorych $[2,4,5]$, jednak według danych pochodzących z piśmiennictwa polskiego i zagranicznego w codziennej praktyce klinicznej odsetek kontroli NiW jest istotnie mniejszy [6-9]. Celem pracy jest przedstawienie i omówienie wyników ankietowego badania obserwacyjnego dotyczącego zastosowania profilaktyki przeciwwymiotnej u chorych poddanych chemioterapii z udziałem cisplatyny w dawce większej niż $70 \mathrm{mg} / \mathrm{m}^{2}$ w ramach rutynowej klinicznej praktyki w ośrodkach onkologicznych w Polsce.

\section{Materiał i metody}

W okresie od czerwca do lipca 2013 roku przeprowadzono badanie ankietowe w grupie 50 onkologów pracujących w ośrodkach onkologicznych w Polsce. Badanie składało się z kwestionariusza dotyczącego opinii lekarzy na temat stosowania leczenia przeciwwymiotnego oraz wypełnianych przez lekarzy kart obserwacji chorych, w których opisywano postępowanie przeciwwymiotne w ramach rutynowej praktyki klinicznej. Łącznie rejestr objął grupę 200 chorych, u których zastosowano wysokoemetogenną chemioterapię zawierającą cisplatynę w dawce przekraczającej $70 \mathrm{mg} / \mathrm{m}^{2}$ powierzchni ciała. Na podstawie wypełnionych przez lekarzy ankiet i kart obserwacji chorych przeprowadzono analizę częstości ordynowania poszczególnych leków, czasu trwania leczenia przeciwwymiotnego oraz skuteczności kontroli nudności i wymiotów.

\section{Wyniki}

W analizowanej grupie 200 chorych otrzymujących cisplatynę w dawce większej niż 70 mg/m², 61\% stanowili mężczyźni i 39\% kobiety. Średnia wieku wyniosła 56 lat. Większość (72\%) chorych, których dotyczyły obserwacje, otrzymywała pierwszą linię chemioterapii. Dwóch chorych nie otrzymało żadnego leczenia przeciwwymiotnego. Według szacunków ankietowanych lekarzy w ich praktyce u 75\% chorych poddanych wysokoemetogennej chemioterapii potencjalne NiW stanowią główną obawę towarzyszącą leczeniu. Jak podało $41 \%$ ankietowanych, brak skuteczności profilaktyki jest głównym problemem związanym z prowadzeniem leczenia przeciwwymiotnego. Wśród leków stosowanych w profilaktyce przeciwwymiotnej wymieniano: antagonistów receptora 5-HT3, antagonistów receptora dla 
Tabela II. Wykorzystanie schematów leczenia przeciwwymiotnego w kolejnych dobach po chemioterapii

\begin{tabular}{lccccc}
\hline Lek & \multicolumn{5}{c}{ Doba po chemioterapii (odsetek chorych), $\mathbf{n = 2 0 0 ~ ( 1 0 0 \% ) ~}$} \\
\cline { 2 - 6 } & $\mathbf{1 .}$ & $\mathbf{2 .}$ & $\mathbf{3}$ & $\mathbf{4}$ & $\mathbf{5}$ \\
\hline aNK1+ dex+ a5-HT3 & $44 \%$ & $18 \%$ & $8 \%$ & - & - \\
a5-HT3 + dex & $40 \%$ & $15 \%$ & $10 \%$ & $7 \%$ & $2 \%$ \\
aNK1 + a5-HT3 & - & $5 \%$ & $7 \%$ & $2 \%$ & - \\
aNK1 + dex & $1 \%$ & $23 \%$ & $26 \%$ & - & - \\
a5-HT3 & $9 \%$ & $9 \%$ & $12 \%$ & $21 \%$ & $20 \%$ \\
dex & $3 \%$ & $4 \%$ & $8 \%$ & - & $9 \%$ \\
inne w monoterapii & $2 \%$ & $2 \%$ & $2 \%$ & $43 \%$ & $7 \%$ \\
brak profilaktyki & $1 \%$ & $24 \%$ & $27 \%$ & $62 \%$ \\
\hline
\end{tabular}

aNK1 - antagonista receptora NK-1, dex — deksametazon, a5-HT3 - antagonista receptora 5-HT3

Tabela III. Grupy leków stosowane w kolejnych dobach po chemioterapii

\begin{tabular}{|c|c|c|c|c|c|}
\hline \multirow[t]{2}{*}{ Lek } & \multicolumn{5}{|c|}{ Doba po chemioterapii (odsetek chorych), n = 200 (100\%) } \\
\hline & 1. & 2. & 3. & 4. & 5. \\
\hline aNK1 & $48 \%$ & $46 \%$ & $43 \%$ & - & - \\
\hline a5-HT3 & $94 \%$ & $48 \%$ & $35 \%$ & $28 \%$ & $22 \%$ \\
\hline dex & $87 \%$ & $60 \%$ & $51 \%$ & $34 \%$ & $11 \%$ \\
\hline inne & $16 \%$ & $9 \%$ & $8 \%$ & $10 \%$ & $12 \%$ \\
\hline brak & $1 \%$ & $24 \%$ & $27 \%$ & $43 \%$ & $62 \%$ \\
\hline
\end{tabular}

aNK1 - antagonista receptora NK-1, dex — deksametazon, a5-HT3 - antagonista receptora 5-HT3

neurokininy-1, antagonistów receptora typu 2. dla dopaminy (D2) oraz kortykosteroidy. Średnia długość podawania antagonistów receptora NK-1 wyniosła 3 dni, a antagonistów receptora 5-HT3 i kortykosteroidów - 5,8 i 5,1 dnia. Leki z innych grup (antagoniści D2, benzodiazepiny i inne) stosowano średnio 4,8 dnia. Na podstawie dostarczonych danych klinicznych 59\% pacjentów otrzymywało leczenie przeciwwymiotne od 3 do 5 dni po podaniu chemioterapii. U 24\% chorych profilaktykę przeciwwymiotną zastosowano tylko w pierwszym dniu chemioterapii. W pierwszej dobie wysokoemetogennej chemioterapii schemat trójlekowy zawierający aprepitant (antagonista NK-1), antagonistę receptora 5-HT3 i deksametazon zastosowano u 44\% chorych, a schemat dwulekowy (antagonista receptora 5-HT3 w skojarzeniu z deksametazonem) u 40\% (tab. II). W drugiej i trzeciej dobie aprepitant w skojarzeniu z deksametazonem zastosowano u $23 \%$ i $26 \%$ chorych. W pozostałych dniach aprepitantu nie stosowano. W pierwszej dobie a5HT-3 podano u $94 \%$ chorych, z których ponad $60 \%$ otrzymało dawkę $8 \mathrm{mg}$ drogą dożylną. Antagonistę receptora 5-HT3 w monoterapii lub w skojarzeniu z innym lekiem zastosowano $w$ kolejnych dobach (od 2. do 5.) odpowiednio u 48\%, 35\%, 28\% i $22 \%$ chorych (tab. III). Glikokortykosteroidy w 2. i 3. dobie podawano u $60 \%$ i $51 \%$ badanych. Monoterapię deksametazonem w czwartej dobie otrzymało $27 \%$ chorych oraz 7\% w skojarzeniu z lekami z grupy setronów. Najczęściej stosowanymi dawkami deksametazonu w pierwszej do- bie było $8 \mathrm{mg}$ (38\%) lub $12 \mathrm{mg}$ (30\%) podane dożylnie. W kolejnych dobach dominowała dawka $8 \mathrm{mg}$ (ponad 60\% chorych) i często obserwowano zmianę drogi podania na doustną. Zaobserwowano, że $80 \%$ badanych przy wypisie ze szpitala otrzymało receptę na preparaty przeciwwymiotne $\mathrm{z}$ zaleceniem stosowania $\mathrm{w}$ domu. Dominowały preparaty ondansetronu (ponad 60\%), deksametazon (28\%), antagoniści receptora D2 (22\%) i inne. W dniach od 2. do 5. po podaniu cisplatyny w dawce powyżej $70 \mathrm{mg} / \mathrm{m}^{2}$ leków przeciwwymiotnych nie stosowano odpowiednio u 24\%, $27 \%, 43 \%$ i $62 \%$ spośród analizowanych 200 chorych. Na podstawie zebranych danych medycznych w grupie otrzymujących wysokoemetogenną chemioterapię nudności wczesne stwierdzono u $49 \%$ chorych, a wymioty u $13 \%$. W fazie opóźnionej, po podaniu chemioterapii zaobserwowano nudności u 38\%, a wymioty u 5\% chorych. Przed kolejnym kursem chemioterapii u $14 \%$ chorych zanotowano nudności przepowiadające, którym u 1\% chorych towarzyszyły wymioty. Nie oceniano intensywności dolegliwości według skali oceny toksyczności CTCAE (common terminology criteria for adverse events) [10]. Całkowity brak wczesnych NiW stwierdzono u $46 \%$ chorych, a brak NiW fazy opóźnionej - u 61\%. Stopień nasilenia NiW określano za pomocą skali wzrokowo-analogowej (VAS — visual-analogue scale), gdzie 0 wyrażało całkowity brak dolegliwości, a maksymalne możliwe nasilenie NiW określano jako 10 punktów (pkt). W całej grupie badanej nasilenie nudności 
Tabela IV. Stopień nasilenia nudności i wymiotów oceniany według skali wzrokowo-analogowej (VAS — visual-analogue scale)

\begin{tabular}{lcccc}
\hline & Schemat trójlekowy & Schemat dwulekowy & Monoterapia i inne & Średnia \\
\hline Nudności wczesne i późne & 1,48 & 1,83 & 2,3 & 1,75 \\
Wymioty wczesne i późne & 0,43 & 0,54 & 0,67 & 0,53 \\
\hline
\end{tabular}

typu wczesnego oraz późnego oszacowano jednakowo: na 1,75 pkt VAS, a nasilenie wymiotów - na 0,53 pkt VAS. W zależności od przyjętego postępowania przeciwwymiotnego najlepsza kontrola nudności w fazie ostrej i opóźnionej dotyczyła schematu trójlekowego (średnie nasilenie VAS - 1,48 pkt) w porównaniu ze schematem dwulekowym (VAS - 1,83 pkt) i monoterapią (VAS - 2,3 pkt). Podobnie schemat trójlekowy najlepiej kontrolował wymioty zarówno fazy wczesnej, jak i późnej (VAS — 0,43 pkt) w porównaniu ze schematem dwulekowym (VAS - 0,54 pkt) i monoterapią (VAS - 0,67 pkt) (tab. IV). Nie przeprowadzono porównawczej analizy statystycznej opisywanych wyników.

\section{Dyskusja}

W odniesieniu do obserwacji pochodzących z prospektywnych badań klinicznych prezentowane wyniki stosowanej w praktyce klinicznej profilaktyki przeciwwymiotnej u chorych poddawanych wysokoemetogennej chemioterapii pozostają niezadowalające. Według danych dostępnych w piśmiennictwie leczenie przeciwwymiotne stosowane zgodnie z przyjętymi wytycznymi prowadzi do kontroli wymiotów typu ostrego u około $80-90 \%$ chorych, a typu późnego u około 60-80\% [3, 6, 11-14]. Należy zauważyć, że w większości badań za całkowitą odpowiedź uznaje się brak wymiotów i konieczności stosowania ratunkowych leków przeciwwymiotnych. W prezentowanym badaniu wymioty wczesne i późne stwierdzono u 13\% i 5\% chorych. Nie ma natomiast informacji, jaka cześć chorych spośród $80 \%$, którzy otrzymali receptę na lek przeciwwymiotny do stosowania w domu, faktycznie ten lek przyjmowała. W porównaniu z opublikowanym w 2013 roku analogicznym badaniem przeprowadzonym od grudnia 2011 roku do stycznia 2012 roku, obejmującym grupę 686 chorych, z których 204 otrzymywało chemioterapię z udziałem cisplatyny w dawce większej niż $70 \mathrm{mg} / \mathrm{m}^{2}$, zaobserwowano poprawę w zakresie kontroli wymiotów typu ostrego i późnego [9]. W obecnym opracowaniu kontrolę NiW wczesnych uzyskano u $46 \%$, a późnych u $61 \%$ chorych w porównaniu z 30\% i 40\% według danych z cytowanej pracy. Prawdopodobnie lepsza kontrola NiW wynika z większej częstości prowadzenia profilaktyki przeciwwymiotnej z zastosowaniem schematu trójlekowego (antagonista receptora NK1, antagonista 5-HT3 i deksametazon). Dane pochodzące z analizy dokumentacji medycznej pacjentów wskazują, że w 2012 roku schemat trójlekowy w dniu 1. chemioterapii zastosowano jedynie u $18 \%$ chorych otrzymujących cispla-
Tabela V. Zalecane postępowanie profilaktyczne w zależności od potencjału emetogennego chemioterapii [16]

\begin{tabular}{ll}
\hline $\begin{array}{l}\text { Ryzyko nudności } \\
\text { i wymiotów }\end{array}$ & Postępowanie \\
\hline Wysokie & aNK-1 $125 \mathrm{mg}-80 \mathrm{mg}-80 \mathrm{mg}$ (dni 1.-3.) \\
& + a5-HT3 (dzień 1.) \\
& + dex $12 \mathrm{mg}$ (dzień 1.) $8 \mathrm{mg}$ (dni 2.-4.) \\
Średnie & a5-HT3 (dzień 1.) \\
& + dex $12 \mathrm{mg}$ (dni 1.-4.) \\
Niskie & dex (dzień 1.) \\
Minimalne & brak \\
\hline
\end{tabular}

aNK1 - antagonista receptora NK-1, dex - deksametazon, a5- $\mathrm{HT} 3$ - antagonista receptora $5-\mathrm{HT} 3$

tynę w dawce przekraczającej $70 \mathrm{mg} / \mathrm{m}^{2}$, a 66\% chorych $z$ tej grupy było leczonych schematem dwulekowym (antagonista 5-HT3 i deksametazon). Natomiast w 2013 roku największa grupa opisywanych chorych (44\%) w dniu 1. otrzymała schemat trójlekowy w porównaniu z 40\% leczonych antagonistą 5HT3 w skojarzeniu z deksametazonem (tab. II). Zwraca uwagę częste profilaktyczne stosowanie antagonistów receptora 5-HT3 w kolejnych dobach po chemioterapii (od $48 \%$ w 2 . dobie do nawet $22 \%$ chorych w 5. dobie). Preparaty z tej grupy były także najczęściej stosowanymi lekami w 5 . dobie oraz przepisywanymi na receptę do domu. Średni czas trwania leczenia ondansetronem wyniósł 5,8 dnia. Zgodnie z aktualnym stanem wiedzy, ze względu na inny patomechanizm NiW, antagoniści receptora 5-HT3 mają niewielki wpływ na kontrolę wymiotów typu późnego oraz minimalny wpływ na przeciwdziałanie wymiotom przepowiadającym [15]. Obowiązujące wytyczne w zakresie przeciwdziałania NiW towarzyszącym wysokoemetogennej chemioterapii wskazują na konieczność zastosowania $w 1$. dobie chemioterapii antagonisty receptora NK1 w skojarzeniu z antagonistą receptora 5-HT3 i deksametazonem [16]. W kolejnych dwóch dobach stosuje się antagonistę receptora NK-1 w połączeniu z deksametazonem i monoterapię deksametazonem w dniu 4. (tab. V). Zastosowanie leków z grupy antagonistów receptora 5-HT3 powinno być ograniczone do dnia 1. chemioterapii o wysokim lub średnim potencjale emetogennym. Nie ma uzasadnienia eskalacja dawki lub wydłużanie czasu trwania leczenia przeciwwymiotnego. Skuteczna kontrola wymiotów typu wczesnego i późnego jednocześnie zmniejsza ryzyko wystąpienia psychogennych wymiotów przepo- 
wiadających przed kolejnym cyklem leczenia [5]. Według dostępnych analiz brak przestrzegania zaleceń w zakresie zapobiegania NiW towarzyszącym chemioterapii zwiększa ryzyko wystąpienia NiW o $31-41 \%$ w porównaniu z prawidłowo prowadzoną profilaktyką $[6,13]$. W opisywanym badaniu wszyscy ankietowani lekarze zadeklarowali, że prowadząc leczenie przeciwwymiotne, kierują się wytycznymi towarzystw naukowych (PTOK - 78\%, ESMO - 74\%, NCCN - 58\%). Natomiast na podstawie dostarczonych kart obserwacji chorych stwierdzono, że w opisywanej grupie 200 chorych, u których stosowano chemioterapię o wysokim ryzyku wystąpienia NiW, zawierającą cisplatynę w dawce przekraczającej $70 \mathrm{mg} / \mathrm{m}^{2}$, profilaktykę przeciwwymiotną zgodnie z zaleceniami zastosowano u około $25 \%$ chorych. W innych krajach odsetek lekarzy prowadzących leczenie przeciwwymiotne zgodnie z przyjętymi wytycznymi jest wyższy, jednak nigdzie nie osiąga $100 \%$ [6, 8, 13, 17, 18]. Należy mieć na uwadze ograniczenia prowadzonego badania i jego retrospektywny charakter. Analizę oparto na odpowiedziach udzielanych przez lekarzy i danych klinicznych z dostarczonych przez ankietowanych kart obserwacji chorych. Nie weryfikowano poprawności wprowadzonych danych z dokumentacjąźródłową. Ze względu na powyższe ograniczenia uzyskanych wyników nie poddano dokładnej analizie statystycznej.

\section{Wnioski}

Obserwacje wynikające z przeprowadzonych ankiet wskazują na utrzymującą się niedostateczną kontrolę wymiotów towarzyszących wysokoemetogennej chemioterapii. W porównaniu z poprzednim opracowaniem notuje się poprawę w zakresie kontroli NiW u chorych otrzymujących chemioterapię zawierającą cisplatynę w dawce większej $\mathrm{niż} 70 \mathrm{mg} / \mathrm{m}^{2}$. Prawdopodobnie jest to związane z większą dostępnością nowoczesnych leków przeciwwymiotnych i częstszym ich stosowaniem zgodnie z obowiązującymi wytycznymi. Ze względu na fakt, że NiW związane z chemioterapią stanowią dolegliwość o istotnym znaczeniu klinicznym, w celu dalszej poprawy ich kontroli istnieje potrzeba stałych szkoleń i monitorowania właściwego postępowania wspomagającego. Stosowanie terapii wspomagającej zgodnie z wytycznymi istotnie wpływa na poprawę jakości życia chorych i realizację leczenia onkologicznego.

Wyniki ankiet na potrzeby niniejszego opracowania zostały dostarczone przez MSD Polska.

\section{Konflikt interesów:}

Boehringer Ingelheim, MSD — komitet doradczy AstraZeneca, BMS, Boehringer Ingelheim, Eli Lilly, MSD, Roche - wykład

\section{Dr n. med. Adam Płużański}

Klinika Nowotworów Płuca i Klatki Piersiowej

Centrum Onkologii — Instytut im. Marii Skłodowskiej-Curie

ul. Roentgena 5, 02-781 Warszawa

e-mail:apluzanski@coi.pl

Otrzymano: 5 marca 2015 r.

Przyjęto do druku: 12 marca 2015 r

\section{Piśmiennictwo}

1. Bloechl-Daum B, Deuson RR, Mavros P i wsp. Delayed nausea and vomiting continue to reduce patients' quality of life after highly and moderately emetogenic chemotherapy despite antiemetic treatment. J Clin Oncol 2006; 24: 4472-4478.

2. Grunberg SM, Warr D, Gralla RJ i wsp. Evaluation of new antiemetic agents and definition of antineoplastic agent emetogenicity — state of the art. Support Care Cancer 2011; 19 Suppl 1: S43-47.

3. Roila F, Herrstedt J, Aapro M i wsp. Guideline update for MASCC and ESMO in the prevention of chemotherapy - and radiotherapy-induced nausea and vomiting: results of the Perugia consensus conference. Ann Oncol 2010; 21 Suppl 5: v232-243.

4. Feyer $\mathrm{P}$, Jordan K. Update and new trends in antiemetic therapy: the continuing need for novel therapies. Ann Oncol 2011; 22: 30-38.

5. Hesketh PJ.Chemotherapy-induced nausea and vomiting. N Engl J Med 2008; 358: 2482-2494.

6. Aapro M, Molassiotis A, Dicato M i wsp. The effect of guideline-consistent antiemetic therapy on chemotherapy-induced nausea and vomiting (CINV): the Pan European Emesis Registry (PEER). Ann Oncol 2012; 23: 1986-1992.

7. De Tursi M, Carella C, Tomao S i wsp. Chemotherapy-induced nausea and vomiting in Italian cancer centers: results of CINVDAY, a prospective, multicenter study. Tumori 2014; 100: 309e-313e.

8. Hori K, Kobayashi N, Atsumi H i wsp. Changes in compliance with Japanese antiemetic guideline for chemotherapy-induced nausea and vomiting: a nationwide survey using a distributed research network. Support Care Cancer 2014; 22: 969-977.

9. Krzakowski M. Nudności i wymioty związane z chemioterapią — obecne postępowanie. Onkol Prak Klin 2013; 9: 16-21.

10. National Cancer Institute. Common Terminology Criteria for Adverse Events (CTCAE) v 4.03. 2010

11. Gralla RJ, de Wit R, Herrstedt J i wsp. Antiemetic efficacy of the neurokinin-1 antagonist, aprepitant, plus a 5HT3 antagonist and a corticosteroid in patients receiving anthracyclines or cyclophosphamide in addition to high-dose cisplatin: analysis of combined data from two Phase III randomized clinical trials. Cancer 2005; 104: 864-868.

12. Warr DG, Grunberg SM, Gralla RJ i wsp. The oral NK(1) antagonist aprepitant for the prevention of acute and delayed chemotherapy-induced nausea and vomiting: Pooled data from 2 randomised, double-blind, placebo controlled trials. Eur J Cancer 2005; 41: 1278-1285.

13. Gilmore JW, Peacock NW, Gu A i wsp. Antiemetic guideline consistency and incidence of chemotherapy-induced nausea and vomiting in US community oncology practice: INSPIRE Study. J Oncol Pract 2014; 10 : 68-74.

14. Hsieh RK, Chan A, Kim HK i wsp. Baseline patient characteristics, incidence of CINV, and physician perception of CINV incidence following moderately and highly emetogenic chemotherapy in Asia Pacific countries. Support Care Cancer 2015; 23: 263-272.

15. Cubeddu LX. Serotonin mechanisms in chemotherapy-induced emesis in cancer patients. Oncology 1996; 53 Suppl 1: 18-25.

16. Kawecki A, Krzakowski M. Nudności i wymioty związane z chemioterapią i radioterapią. W: Krzakowski M, Warzocha K (red.) Zalecenia postepowania diagnostyczno-terapeutycznego wnowotworach złośliwych 2013 rok. Gdańsk: Via Medica 2013; 586-597.

17. Fabi A, Barduagni M, Lauro S i wsp. Is delayed chemotherapy-induced emesis well managed in oncological clinical practice? An observational study. Support Care Cancer 2003; 11: 156-161.

18. Kadakia KC, Leal AD, Seisler DK i wsp. Antiemetic prescribing practices using a computerized physician order entry system. Support Care Cancer 2014; 22: 217-223. 